\title{
The Discourse Analysis and Pragmatic meanings of ta:lS in Jordanian Spoken Arabic
}

\author{
Hatmal Odeh Al-Khalidy ${ }^{1}$ \\ ${ }^{1}$ Department of English, Al baha University, Al baha, Saudi Arabia \\ Correspondence: Hatmal Odeh Al-Khalidy, Department of English, Al baha University, Al baha, Saudi Arabia. \\ E-mail: hatmal88@yahoo.com
}

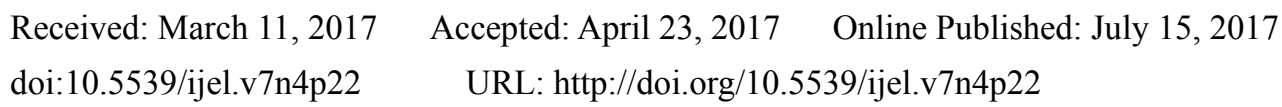

\begin{abstract}
The current study attempts to investigate the discourse analysis and pragmatic meanings of the discourse marker ta:lS in Jordanian Spoken Arabic as used in TV comedy series. The data analyzed consisted of some YouTube videos each one lasted approximately for 45 minutes whereas some of them lasted nearly for 15 minutes. The investigator found that, ta:l $l$ has eight different meanings based on the context in which it is used. Moreover, the recordings were transcribed and analyzed for the purpose of identifying the of ta:lई from a discourse and pragmatics analytical point of view.
\end{abstract}

Keywords: discourse analysis, pragmatics, Jordanian spoken Arabic, translation, transliteration

\section{Introduction}

Discourse analysis concerns with the analysis of language in use, and it studies the purposes and functions of linguistic forms Brown \& Yule (1983). Also, discourse can be defined as "language beyond the sentence" actually discourse analysis is focused on the study of language in both conversation and text as well Yule (2010, p. 142). Potter \& Wetherell (1987) confirm that discourse analysis is nothing but an approach which extends to cover conversation analysis and speech act theory. According to him, discourse deals with all forms of written texts and also, formal and informal spoken interactions. Yule (1966, p. 3) defines "pragmatics is the study of meaning as communicated by a speaker or writer and interpreted by a listener or reader". Pragmatics as a study of speaker meaning, therefore, the focus will be on what people mean by their utterances rather than what the words and phrases mean by themselves.

This study focuses on the discourse analysis and pragmatics meanings of $t a: l \varsigma$ in Jordanian spoken Arabic as in comedy series. (the symbol \& represents the voiced pharyngeal consonant in Arabic). Swamy (2010) argues that not only we try to understand written and spoken forms of words but also, the intended meaning of the writer and speaker. Fraser (1990) distinguishes between two types of meanings for a sentence; pragmatic meaning which related to speaker's intention (illocutionary meaning), and content which mean every sentence conveys a single message.

Wittgenstein (1953, p. 43) states that "The meaning of a word is its use in the language." Therefore, there are different interpretations in different contexts for the same word.

In fact, there is a close relationship between culture and language, which have to be taken equally in the process of translation. Translators should focus on the same conceptual meaning of a text and the differences between two cultural perspectives as well (Abbasi et al., 2012). Furthermore, culture and language are complementary in translation. So, translators transform the cultural perspectives of a text into the target language. Moreover, translation play an important role in cultures globalization in terms of transferring ethnic, customs, social habits or religious values etc. (Abbasi et al., 2012).

Komissarov (1991) claims that people of the same linguistic community have the same culture like, the way of saying things, the ways of doing things, traditions and habits which are very important for the interlocutors' presupposition in order to understand messages in their linguistic form. Also, this common piece of information is required when communication happens between two individuals belong to different cultures and it may become difficult to understand the actual message (Komissarov, 1991). Similarly, Komissarov (1991, p. 34) states "to overcome the linguistic barrier, the translator has to surmount the cultural barrier, to make sure that the 
receptors of the target text are provided with the presuppositions required for their access to the message contents."

\section{Review of Literature}

Kanakri \& Al Harahsheh (2013) investigate the pragmatic functions of the DM $\{a$ :di which literally means normally, usually in Jordanian spoken Arabic. They found that $\{a$ :di has multiple functions depends on the context in which it is used. However, this particular DM was used to mitigate the effects of sad news, to ask for a permission to do something, to express the meaning of disapproval or rebuke, to show disappointment regarding a certain action, to express contempt, to express courtesy, to show acceptance, to save one's face, to show indifference and to express an indirect criticism.

Similarly, Al Harahsheh \& Kanakri (2013) study the pragmatic functions of the Jordanian spoken Arabic DM tayyib meaning "Okay", "fine", literally "good" and its cognate $t a b b$. They stated that these two linguistic terms are functional convey ten different pragmatic functions namely: to mark backchannel with what precedes them, to mean stop or let us understand the matter, to show an objection to what has been said, to introduce a new topic, to be used as mitigating term for disagreement, to express challenge or confrontation, to signal the end of discourse, to send a message to the interlocutor to be patient, to give permission and to be used as gap fillers.

Alazzawie (2015) examines the use of $\{a$ :di It's distribution and It's varied context-dependent meanings and functions. He concludes that $\varsigma a$ :di may serve to perform the following functions: to offer of material support and sympathy, for consolation mitigation and encouragement, acceptance of a proposal, disapproval reprimand and indignation, politeness and courtesy, to mild criticism and sarcasm, for requesting and granting permission, for indifference and obliviousness, A hedging device of softening criticism and face-saving, for resignation and submission or surrender to something beyond one's control, for divergence in opinion and counter proposal, assurance / facilitation and confirmation seeker.

Abdeljawad \& Abu Radwan (2016) examine discourse marker Inzeen in Arabian Gulf spoken variety of Arabic which corresponds to Okay in spoken English. They identified the following sets of the functions of this marker as an agreement (acceptance) marker, a challenge/threat marker, a topic management marker, an interactive marker, a tag marker, a structural marker and a cohesive marker.

Al-Ghoweri (2016) investigates the use and pragmatic functions of "abalakom Allah" (may God elevate you) in Jordanian spoken Arabic. The researcher claims that Jordanians use "alalakom Allah" (God elevate you) when they talk about animals, impure places and reprehensible situations.

Alazzawie (2014) states the lexical item yamawwad in Iraqi Arabic as a functional discourse unit with several different functions that are dependent upon context. Therefore, he came out with seventeen varied functions as follows: it may have rather a general introductory function to open a conversation, it may function as a marker of politeness and courtesy, it can be uttered alone as a pragmatically complete unit that substitutes for a sentence to express more than one function, it can also be interpreted as a request or a gentle imperative to get people to do something, it can express displeasure, annoyance and irritation, it can convey furiousness and indignation, pleading, apologizing and admitting responsibility, it may serve as a phatic utterance expressing solidarity and empathy, it may administer a rebuke, it can be adversative in function expressing disagreement and opposition to a given proposition, it can have an explicative function, it can be an expression of surprise and astonishment at an unexpected outcome, to express strong will and determination in the face difficulty and adversity, warning of an imminent danger resentment and refusal, disappointment and total resignation and finally, used for hope and expectancy.

Al-Rousan (2015) examines the use of discourse marker "maS nafsak" in Saudi Arabic. The study revealed that "maS nafsak" gives twelve different pragmatic functions based on the context in which is used as the following: objection or refusal, lack of interest/carelessness/ indifference, annoyance, reprimanding, doubt, unwillingness, distancing one's self from others, challenge, scolding, disappointment, choice and preserving personal privacy.

\section{Methodology and Theoretical Framework}

The methodology of this paper draws on discourse analysis, conversation analysis and pragmatic analysis of the Jordanian spoken Arabic DM ta:l؟ which was translated and transliterated. The investigator collected the data of this paper after listening to two comedy series telecast by Jordanian television in spoken Jordanian Arabic which were highlighting the social and economic problems of Jordanian society during that period. One of these comedy series named Abu Awwad was telecasted in the year 1981 consisting of 12 episodes of approximately 45 minutes each. The other comedy series named Ghafil ghawi mashakil was telecasted in the year 2014 featuring 28 episodes of around 15 minutes each. Moreover, both of the comedy series can be accessed on YouTube videos. 
The researcher has had the privilege to watch the series during a period of more or less a month beginning from $15^{\text {th }}$ June 2016 to $15^{\text {th }}$ July 2016.

\section{Findings}

The data analysis came out with eight different pragmatic meanings of Jordanian spoken Arabic DM ta:ls. They were classified under 8 different categories. The following are examples of these categories supported by illustrative examples taken exactly as they appeared in the Jordanian comedy series with their translations and transliterations. The data shows that DM ta:l $l$ gives the following pragmatic meanings:

\section{1). Going}

Background a merchant was telling his friend, I will be a broker and I will increase my income, I will be like a saw-gain while going and gain while returning.

J رح اصير زي المنشارطالع بقص نازل بقص [Arabic Text]

[Transliteration] rah aseer ziel munshar $t a: l \varsigma$ ba qos nazl ba qos

[Translation] I will be like a saw_-gaining while it go and gain while it returns.

\section{2). Going out}

Background someone went to visit his friend who has been admitted to a hospital and a nurse saw him and said, the man (the patient) has just gone out of the ICU room.

[Arabic Text] الزلمة طالع من الانعاش

[Transliteration] Azalama ta:l\$ min al in 9 ash

[Translation] The man has just gone out of the ICU room.

\section{3). Hearable}

Background neighbors heard a loud voice coming from their neighbor's house so; they ran to his house and asked him, what is the voice which is hearable from your side?

[Arabic Text] [و الصوت طالع من عندك؟

[Transliteration] shoo asout ta:lS min Sendak

[Translation] What is the voice which is hearable from your side?

4). Appear

Background a man used to see someone wherever he goes so, that man said you always appear before my eyes.

[Arabic Text] [الع لي بالسحبة

[Transliteration] ta:ls li bil sahba

[Translation] You always appear before my eyes.

\section{5). Looks like}

Background a husband was explaining to his wife and neighbors that the son looks like his father.

[Arabic Text] الولد طالع لابوه

[Transliteration] alwalad $t a: l s$ la abooh

[Translation] The son looks like his father.

\section{6). Share}

Background a rich man died and left many properties which have to be distributed for his sons and daughters so, a husband of one of these daughters was inquiring and said: I don't know how much share she will inherit.

[Arabic Text] بس بعرفش قديش طالع الها من الورثة

[Transliteration] bas b?rafish gadash $t a: l S$ ilha min elwer0a

[Translation] I don't know how much share she will inherit.

\section{7). Ascending}

Background policemen were trying to catch a thief who was running to enter a building, the thief asked for a permission that allows him to go inside the house. By telling please help me to hide from the policemen those are ascending the stairs now. 
[Arabic Text] طالعين الدرج

[Transliteration] ta:lYeen adaraj (the suffix-een marks plurality)

[Translation] They are ascending the stairs now.

\section{8). From now on}

Background a man was angry upon someone else so, he told him from now on, I don't want to speak to you anymore.

\section{[Arabic Text] من اليوم و طالع]}

[Transliteration] min elyoom wa $t a: l \varsigma$

[Translation] From now on.

\section{Discussion}

Having a close look at the above mentioned examples, the current study reveals that the discourse marker $t a: l \varsigma$ gives various functions according to their contexts and situations. However, the context and the situation play a crucial role in the interpretation of DM ta:l . Its meaning depends on the context in which it is used. Fraster (1987); Lenk (1998) and Schiffrin (1987) point out in oral discourse, DMs gets their meaning from the context. Yule (ibid, p. 3) defines pragmatics "as the study of how more gets communicated than is said."

In addition, the above analysis has shown that the DM ta:lS in Jordanian spoken Arabic occurred in three different positions middle, initial and final respectively. Out of (8) times the occurrence of DM ta:l§ in Jordanian spoken Arabic has occurred (5) times in the middle position this followed by initial position (2) and final position (1).

Finally, the DM ta:ls has occurred in the positions to show various functions according to their contexts and situations in Jordanian spoken Arabic as the following :

\subsection{The Occurrence of DM ta:lS in the Middle Position}

\subsubsection{Going}

رح اصير زي المنثار طالع بقص نازل بقص

rah aseer ziel munshar ta:l\$ ba qos nazl ba qos

I will be like a saw_-gaining while it go and gain while it returns.

\subsubsection{Going Out}

الزلمة طالع من الانعاش

Azalama $t a: l \varsigma$ min al infash

The man has just gone out of the ICU room.

\subsubsection{Hearable}

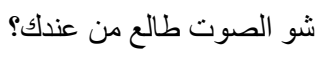

shoo asout ta:l؟ min $\subseteq$ endak

What is the voice which is hearable from your side?

You always appear before my eyes.

\subsubsection{Looks Like}

الولا طالع لابوه

alwalad ta:ls la abooh

The son looks like his father.

5.1.5 Share

بس بعرفش قديش طالع الها من الورثة

bas b?rafish gadash ta:ls ilha min elwer0a

I don't know how much share she will inherit. 
5.2 The Occurrence of DM ta:ls in the Initial Position

5.2.1 Appear

ta:ls li bil sahba

5.2.2 Ascending

طالعين الدرج

ta:l een adaraj (the suffix -een marks plurality)

They are ascending the stairs now.

\subsection{The Occurrence of DM ta:ls in the Final Position}

\subsubsection{From Now On}

من اليومو طالع

min elyoom wa $t a: l \varsigma$

From now on.

\section{Conclusion}

The present study has investigated the pragmatic meanings of DM ta:lS in Jordanian spoken Arabic. The analysis of DM ta:ls in Jordanian comedy You Tube videos revealed that ta:ls has the following pragmatic meanings: going, going out, hearable, appear, looks like, share, ascending and from now on.

Finally, Arabic language and Jordanian spoken Arabic as well are very rich linguistic environments for various researches. This study has been limited for the pragmatic meanings of the Arabic DM ta:ls only. Similar studies can be taken up to study different words with reference to linguistic phenomena in Arabic and its dialects such as Gulf dialect, Iraqi dialect, Egyptian dialect etc. we hope that this study motivates many linguists to focus on some similar linguistic phenomena in Arabic and it's dialects in the nearest future.

\section{References}

Abbasi, G., Zadeh, S. S., Janfaz, E., Assemi, A., \& Dehghan, S. S. (2012). Language, Translation and Culture. 2012 International Conference on Language, Medias and Culture IPEDR, 33.

Abdeljawad \& Abu Radwan (2016). Conversational Coherence: The Role of Inzeen (Okay) In Arabian Gulf Spoken Arabic. International Journal of Arabic linguistics (IJAL), 2(1), 1-18.

Al Rousan, R. (2015). The Use of Discourse Marker "ma؟ nafsak" in Saudi Arabic: A Pragmatic Perspective. International Journal of Linguistics, 7(3), 33-48. https://doi.org/10.5296/ijl.v7i3.7669

Alazzawie, A. (2014). Yamawwad: A Discourse and Pragmatic Marker in Iraqi Arabic. World Journal of English Language, 4(2), 30-39. https://doi.org/10.5430/wjel.v4n2p30

Alazzawie, A. (2015). Padi as a Discourse Marker in Spoken Iraqi Arabic. Theory and Practice in Language Studies, 5(7), 1352-1360. https://doi.org/10.17507/tpls.0507.06

Al-Ghoweri, H. (2016). Pragmatic Functions of abalakom'allah (May God elevate you) in Jordanian Spoken Arabic. Imperial Journal of Interdisciplinary Research (IJIR), 2(6), 271-274.

Al-Harahsheh, A., \& Kanakri, M. (2013). The Pragmatic Functions and the Translatability of "Tayib" in Jordanian Spoken Arabic. US-China Foreign Language, 11(3), 196-202.

Brown, L., \& Yule, G. (1983). Discourse analysis. Cambridge: Cambridge University Press. https://doi.org/10.1017/CBO9780511805226

Fraser, B. (1987). Pragmatic formatives. In J. Verschueren \& Bertuccelli-Papi (Eds.), The Pragmatic Perspective (pp. 197-194). Amsterdam: Benjamins. https://doi.org/10.1075/pbcs.5.14fra

Fraser, B. (1990). An approach to discourse markers. Journal of Pragmatics, 14, 383-395. https://doi.org/10.1016/0378-2166(90)90096-V

Kanakri, M., \& Al-Harahsheh, A. (2013). The Discourse Analysis of "Pa:di" in Jordanian Spoken Arabic. International Journal of English Linguistics, 3(6), 59-63. https://doi.org/10.5539/ijel.v3n6p59

Komissarov, V. N. (1991). Language and Culture in Translation: Competitors or Collaborators? TTR: Traduction, Terminologie, Rédaction, 4(1), 33-47. 
Lenk, U. (1997). "Discourse markers". Handbook of Pragmatics.

Lenk, U. (1998). Discourse Markers and Global Coherence in Conversation. Journal of Pragmatics, 30(2), 245-257. https://doi.org/10.1016/S0378-2166(98)00027-7

Narasimhaswamy, K. V. (2010). Linguistics and English Language Teaching (1st ed.). Mysore: Shruthiloka Prakashana.

Potter, J., \& Wetherell, M. (1987). Discourse and social psychology: beyond attitudes and behavior. London.

Schiffrin, D. (1987). Discourse markers. Cambridge: Cambridge University Press. https://doi.org/10.1017/CBO9780511611841

Wittgenstein, L. (1958). Philosophical Investigations (2nd ed., G. E. M. Anscombe, Trans.). Oxford: Blackwell.

Yule, G. (1996). Pragmatics. Oxford, UK: Oxford University Press.

Yule, G. (2010). The Study of Language (4th ed.). Cambridge, United Kingdom: Cambridge University Press. https://doi.org/10.1017/CBO9780511757754

\section{Copyrights}

Copyright for this article is retained by the author(s), with first publication rights granted to the journal.

This is an open-access article distributed under the terms and conditions of the Creative Commons Attribution license (http://creativecommons.org/licenses/by/4.0/). 